$$
\begin{aligned}
& \text { قسم الجرا احســـــــة والــــــلادة } \\
& \text { كلية الطب البيطري - جامعة الاسكندرية }
\end{aligned}
$$

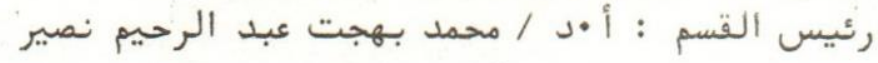

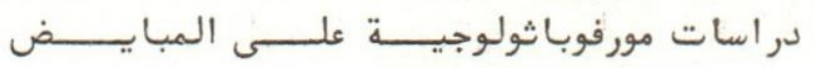

$$
\begin{aligned}
& \text { وقناة المبيض والرحم فى حالة تحوصل المبايض فى الجمال }
\end{aligned}
$$$$
\text { فكرى محمد حسين ، مصطفى منصور حسبيب }
$$

تم اجر اء البحث على عدد 79 عينة تتسلية غير عشار من أنثى الجمل ثم الحمــــول

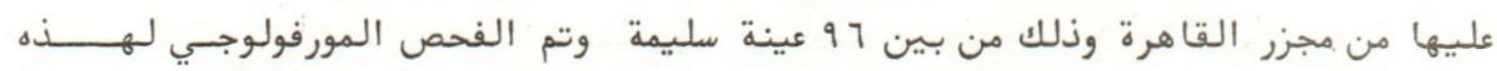
العينـات تبين وجود أربع حالات مصابة بتحوصل المبايض وكان أكثرها فى المبيض الايمسن وتتراوح قطرها هن ك سم الى ا, عـ سعم

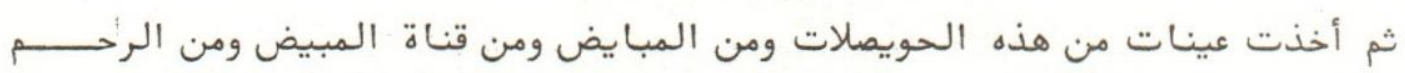

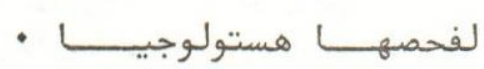


Dept. of Gynaecology, Obestetrics and A.I., Faculty of Vet. Med., Alexandria University, Head of Dept. Prof. Dr. M.B. Noseir.

\title{
MORPHOPATHOLOGICAL STUDIES ON THE OVARIES, OVIDUCTS AND UTERI FROM CAMELS WITH CYSTIC OVARIES \\ (With 10 Figs.)
}

\author{
By \\ F.M. HUSSEIN and M.M. HASSIEB* \\ (Received at 29/6/1988)
}

\begin{abstract}
SUMMARY
A total of 96 non-pregnant camel's genitalia collected from Cairo slaughter house were included in this study. There were 4 cases of the examined genitalia having ovarian cystic structures. These ovarian cysts were observed at the right and left sides, their diameters varied from 2 to $4.1 \mathrm{~cm}$. The gross histopathological examination of these ovarian cysts along with the ovaries, oviducts and uteri, were carried out.
\end{abstract}

\section{INTRODUCTION}

Cystic ovarian disease is one of the commonest and the most serious causes of infertility in ruminants (ROBERTS, 1971). The basement membrane, of the ovarian cysts, was reported to be the first degenerated layer (AL-DAHASH and DAVID, 1977 in cows; EL-AZAB; SHARAWY, BALAH; HAMZAA, BAREEDY and NASR, 1984 in buffaloes and SARUR; EL-SAYED; RAGAB and EISSA, 1987 in camel). The granulosa cells, which are the site responsible for oestrogen production (ROBERTS, 1971), are gradually destroyed due to the continous distention of the cyst (MECKENZIE and KENNEY, 1973). The normal follicular structure characterized by two differentiated thece layer; interna and externa (TRAUTMANN and FIEBIGER, 1952). This manner changed in those cystic follicular structures where the two theca layers can't be differentiated (SERUR, et al. 1987). In the cystic cows without corpus luteum the thickness of the endometrium was wider in those where luteinisation of the theca was present. The widness of the endometrium depend upon the degree of luteinisation (AL-DAHASH and DAVID, 1977).

The present work aimed to study the gross-histopathological changes associated with ovarian cysts in camels along with the changes in the oviducts and uteri present with this deffection.

\section{MATERIAL and METHODS}

Four cases of female camel genitalia having ovarian cysts were collected from total of 96 non-pregnant camel genitalias examined at Cairo slaughter house. They were grosely examined for presence of ovarian cysts and other associated changes in the oviducts and uterine horns. Specimens were collected from affected ovaries, ovarian cysts, oviducts as well as from the

* Dept. of Pathology \& Parasitology, Fac. of Vet. Med., Alexandria Univ. 


\section{HUSSEIN and HASSIEB}

uteri. These collected specimens were fixed in $10 \%$ neutral buffer formalin solution and histological sections of five micron thickeness were prepared and stained with haematoxylin and eosin stain (CARLETON and DRURY, 1967).

\section{RESULTS}

Macroscopic appearance of the ovarian cysts with oviducts and uterine horns in the vicinty:

The 1st type of the ovarian cysts was detected on the right side in the form of large, dark-brown to grayish coloured cyst (Fig. 1). Its cut section showed grayish-white gelatinous contents while its cystic wall was hyperaemic and haemorrhagic (Fig. 2). The oviducts and uterine horns were apparently normal.

The 2nd type of the ovarian cysts was also detected on the right side but in the form of large, pale cyst (Fig. 1) with a clear serous fluid in its lumen. The oviducts and uterine horns were similar to the previous case.

The 3rd ovarian cystic type was detected on the left side and appeared also as a large and pale cyst but with a superficialy congested blood vesels (Fig. 3). Its lumen contained also clear serous fluid. The oviducts and uterine horns were also apparently normal.

The last case of female genitalia was important regarding presence of large and pale cyst on the right ovary and a multiple, small sized grayish cystic follicles on the left one (Fig. 4). The oviduct of the left side was slightly dilated and contained some secretory fluids. The uterine horns of both sides were found symmtrical although the left horn was enlarged and hypertrophied and contained some viscid secretions in its lumen.

The ather examined non-pregnant camel genitalia were found apparently normal and have no cystic structures on its ovaries while oviducts were of normal size and the uterine horns were symmtrical and of apparently normal size.

Histopathological studies of the ovarian cysts, the oviducts and uterine horns in the vicinty:

(1) The ovarian cysts, of the 1st case as shown in Fig. 5 and 6, appeared without a basement membrane while its granulosa cells were degenerated and atrophied and only few of normal cells could be detected. The epithelial cells of the theca interna were degenerated and extensively infiltrated by numerous leucocytes while the theca externa became thickened due to fibrous tissue proliferations. The lumen contained dark-eosinophilic contents. In other areas the cystic wall contained numerous congested capillaries and haemorrhagic or bloody areas.

The ovary of the same side showing some degenerated growing follicles which were affected by extensive leucocytic infiltrations in its wall and also in the surrounding tissue (Fig. 7). The oviduct of the right side showed hyperplasia in their epithelial lining which gave some papillary projections into the lumen (Fig. 8). The uterine horn of this side showed degenerated surface epithelium while the endometrial glands were of less active secretory function and became nearly atrophied.

(2) The large pale ovarian cysts, observed in the 2nd, 3rd and 4th cases, were somewhat similar to each other. These cysts were devoid of the granulosa cells while the two theca layers (interna and externa) were undifferentiated and appeared as one fibrous layer, their lumina contained pale eosinophilic serous fluid.

Assiut Vet.Med.J. Vol. 21, No. 41, 1989. 


\section{CYSTIC OVARIES IN CAMELS}

The microscopical appearance of both oviducts and uterine horns of the same side of these cysts were nearly similar to those described in the 1st case in association with the large haemorrhagic ovarian cyst.

(3) The multiple small follicular cysts, which were observed on the left ovary of the 4 th case, had a more thickened cystic walls. They were linned by multiple, slightly degenerated, granulosa cell layers, the normal two theca layers were difficult to be differentiated, and mainly formed of fibrous layers (Fig. 9). Some of the follicles became either atretic or their granulosa cells showed hydropic degeneration and invaded by leutin cells (Fig. 10). The oviduct of the same side showed some hyperplastic changes in some areas. The uterine horn of the same side, showed thickening of the uterine wall due to hyperplasia and active secretory function of the endometrial glands, while the uterine surface epithelium was slightly degenerated.

(4) The other non-cystic ovaries, which were examined in our survey were histologicaly normal. Also the oviducts and uterine horns of the various cases were not microscopically altered.

\section{DISCUSSION}

The observed ovarian cysts were mostly unilateral particularly on the right side. Except the third one (Fig. 3) was found on the left side. Only one of these examined genitalia carried a large pale cyst on the right ovary while the left one contained multiple small follicular cysts.

The diameters of the examined ovarian cysts of the present survey were varied from 2 to $4.1 \mathrm{~cm}$. These ovarian cysts appear in the form of a large circumscribed structure of pale colouration, their lumena generally contained clear serous fluids. The only exception was that large cyst which was dark-brown to grayish colour while its cut section showed haemorrhagic cystic wall and grayish white gelatinous lumenal contents.

Generally all these large and persistant cystic structures in our results were accompanied by normal sized and symetrical oviducts and uterine horns. Only the last case, which carried a haemorrhagic cyst on the right ovary in addition to a multiple small folicular cysts on the other left ovary, showed asymmetrical uterine horns where the left horn was larger.

Histologically, the cysts examined in this survey showed considerable variations. Their differences could have a brearing on the aetiology of the condition and might cast some light on the variety of behaviour seen in camels with cystic ovaries. Firstly the vascular changes and leucocytic infiltrations, which were seen in the 1st ovarian cystic type, may throw some light on that inflammatory alterations in the ovarian cyst which may be either due to trauma or invasion of some microorganisms.

The histopathological examination, of most of all the examined large persistant ovarian cysts of our survey, revealed the absence of the basement membrane. This is in agreement with the results of SERUR, et al. (1987) in camels; AL-DAHASH and DAVID (1977) in cows, and EL-AZAB, et al. (1984) in buffaloes. The basement membrane appeared to be the first degenerated layer due to the expansion of the cyst with increased amount of liquor folliculi.

The degeneration, atrophy and decrease in the numbers of granulosa cells and epithelial cells of theca interna, of the various ovarian cysts in our survey, are confirmed with the results of MCKENZIE and KENNEY (1973). They stated that follicles undergoing cystic atresia were the same microscopically as those undergoing cystic degeneration. They continued to be distended 


\section{HUSSEIN and HASSIEB}

until all granulosa cells and theca epithelial cells disappeared. The degeneration and disappearance of the granulosa cells in mainly due to the continuous distens of the cyst which gradually destroy the granulosa cells until they disappeared completely. Therefore the older cyst has little granulosa cells than the younger ones.

The histopathological examination of the large cysts, revealed also difficulty in the recoginsion of the normal two theca layers which became in the form of one fibrous layer. This finding was in agreement with the finding of SERUR, et al. (1987) in camels and in contrast to the normal follicular structures composed of easily recognized theca interna and theca externa (TRAUTMANN and FIEBIGER, 1952).

The assymmetry in the left side, that accompanied atretic, degenerated and leutinised follicles in the left ovary, showed a wider and thickened endometrium. Similar results were reported by AL-DAHASH and DAVID (1977) in cows and EL-AZAB, et al. (1984) in buffaloes. This thickening of the endometrium was dependant on the amount of leutinisation in the ovarian associated with the wider the endometrial thickening. The fact probably

\section{REFERENCES}

Al-Dahash, S.Y.A. and David, J.S. (1977): Histological examination of the ovaries and uteri from cows with cystic ovary. Vet. Rec. 101: 342-347.

Carleton, M.A. and Drury, R.A.B. (1967): Carlaton's histological technique. 3rd Ed., Oxford, Univ. Press, New York, Toronto.

El-Azab, M.A.; Sharawy, S.M.; Balah, A.M.M.; Hamzaa, A.M.; Bareedy, M.M. and Nasr, M.T. (1984): Histological and histochemical picture of the ovarian cyst with regard to the endometrial changes. Egypt. Vet. Med. Ass. J., 44: 27-39.

Meckenzie, B.E. and Kenney, R.M. (1973): Histologic features of ovarian follicles of Gonadotropin injected heifers. Am. J. Vet. Res., 34 (8): 1033-1040. Roberts, S.J. (1971): Veterinary obstetrics and genital diseases, 2nd Ed., Inc. Ann. Arbor Michigan,
Page 421.

Serur, B.H.; El-Sayed, M.A.l.; Ragab, R.S.A. and Eissa, H.M. (1987): Histopathological changes of the ovaries and uteri in camels with cystic ovaries. Alex. J. Vet. Sci., Vol. 3, No. 1. Trautmann, A. and Fiebiger, J. (1952): The histology of domestic animals. Bailliere, Tindall and
Cox, London.

\section{LEGEND OF FIGURES}

Fig. (1): Female camel genitalia showing large, haemorrhagic and dark brown ovarian cyst on the right side. (The right genitalia). The left genitalia carried a second type
of large pale ovarian cyst on the right side.

Fig. (2): Cut section of the first large and dark-brown ovarian cyst of fig. 1, showing hyperaemic and haemorrhagic cystic wall, while the lumen contains grayish-white gelatinous
contents.

Fig. (3): The 3rd case of ovarian cyst on the left side, appeared as a large and pale cyst
with a superficial congested blood vessels. 


\section{CYSTIC OVARIES IN CAMELS}

Fig. (4): The last case of ovarian cyst showing large and pale cyst on the right ovary, while the left ovary carried a multiple, small sized and grayish cystic follicles. The uterine horn of the left side is enlarged and as symetrical with the right side.

Fig. (5): The 1st case of ovarian cysts showing: dark-eosinophilic lumenal contents (A), absence of the basement membrane, degeneration and atrophy of the granulosa cells (B), degeneration of the epithelial cells of the theca interna with leucocytic infiltration (C) and fibrous thickening of the theca externa ( $H$ \& E. X 400).

Fig. (6): Another area of the cystic wall of the 1st case, showing congested capillaries and haemorrhagic or bloody areas. ( $H$ \& E. X 400).

Fig. (7): Right ovary of the same 1st case, showing degenerated growing follicle with extensive leucocytic aggregations in its wall and also infiltrations into the surrounding tissues ( $H$ \& E. X 63).

Fig. (8): The oviduct of the right side of the 1st case, showing hyperplasia of the epithelial lining with numerous papillary projections into the lumen. ( $H$ \& E. X 63).

Fig. (9): Two small cystic follicles, on the left ovary of the last case, showing multiple granulosa cell layers while the two theca layers are fused into one fibrous layer. ( $H$ \& E. $\times$ 63).

Fig. (10): The left ovary of the last case showing showing large follicle with hydropic degenerated granulosa cells $(A)$ and groups of leutinising cells invade the follicular wall (B). (H \& E. X 160).

Assiut Vet.Med.J. Vol. 21, No. 41, 1989. 

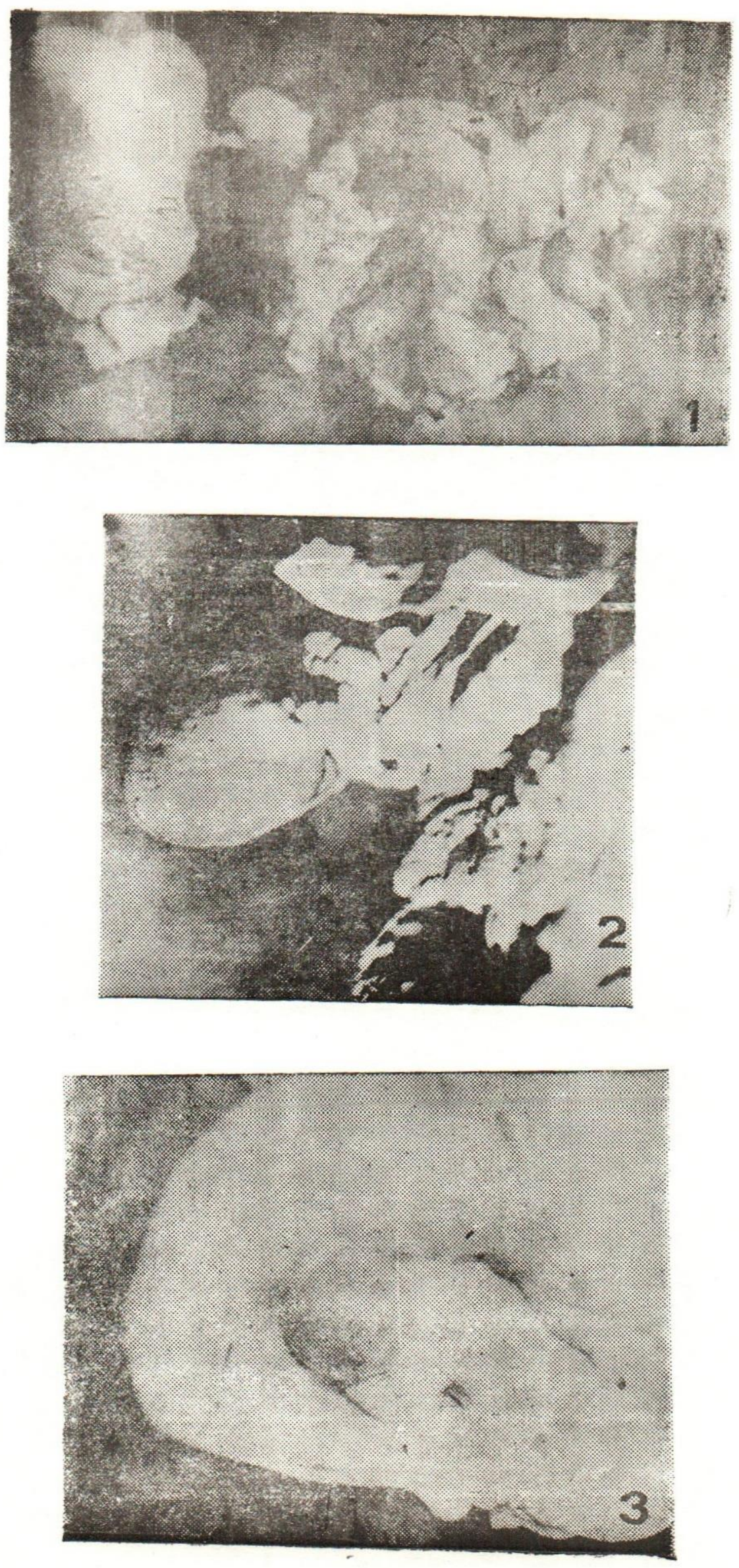

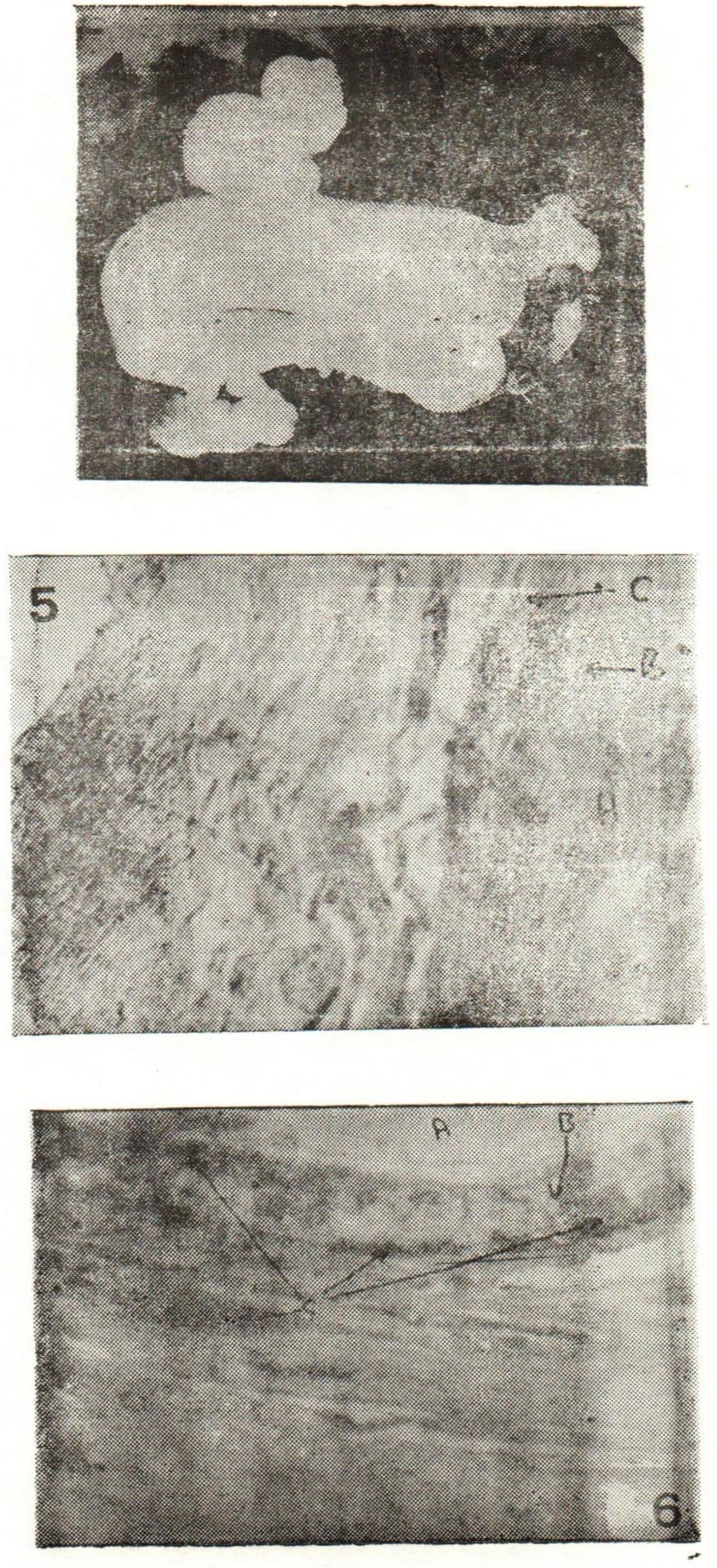

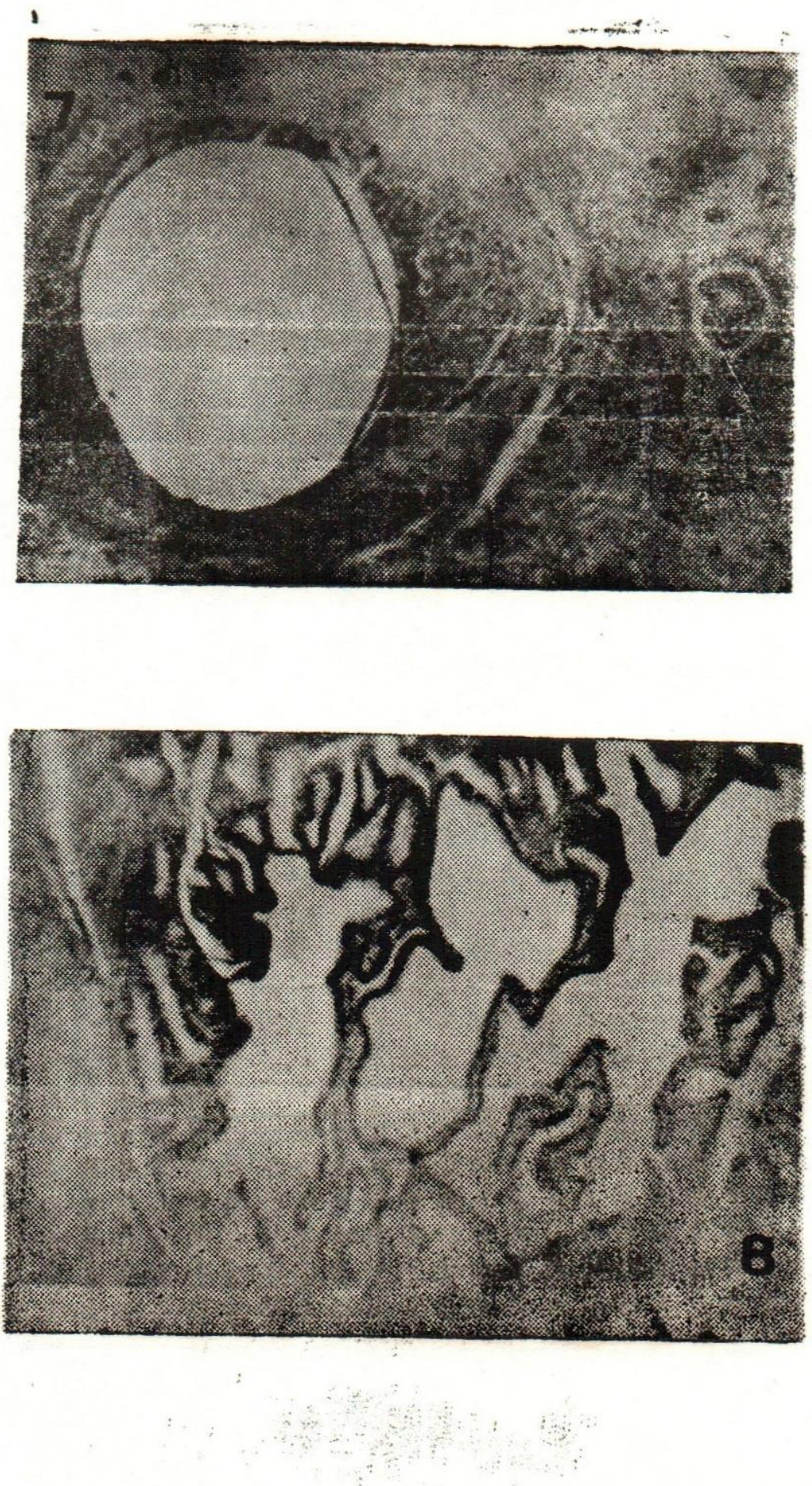
\&

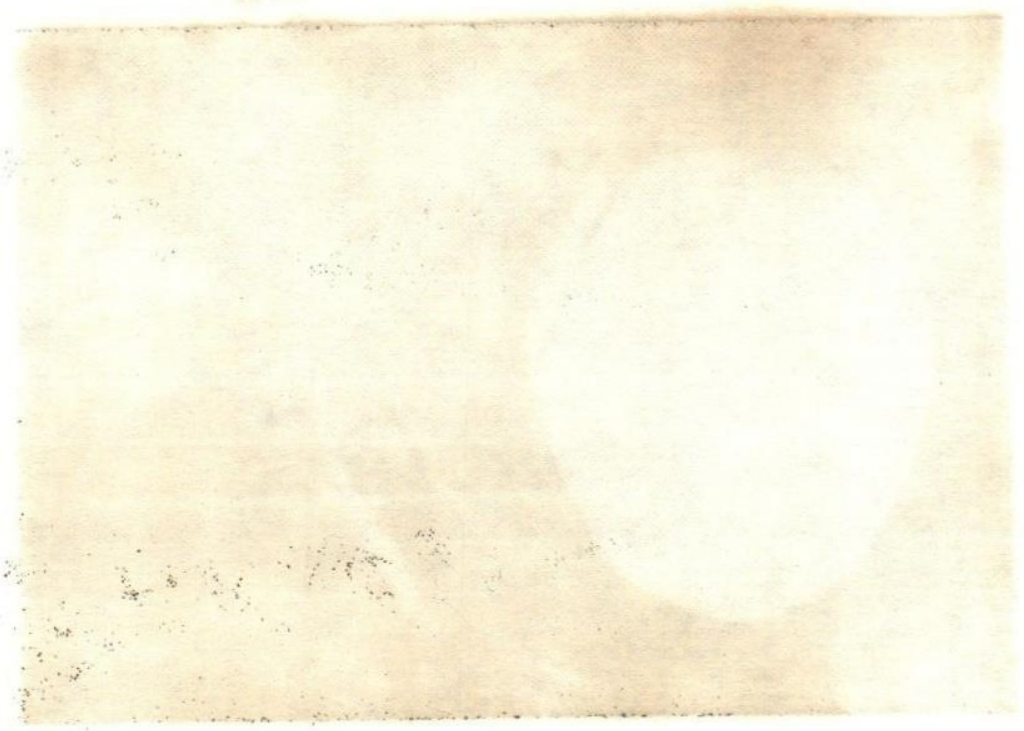

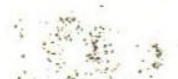

$\frac{n^{2}}{4}$

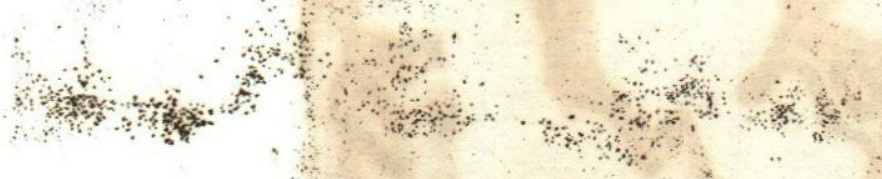

स:

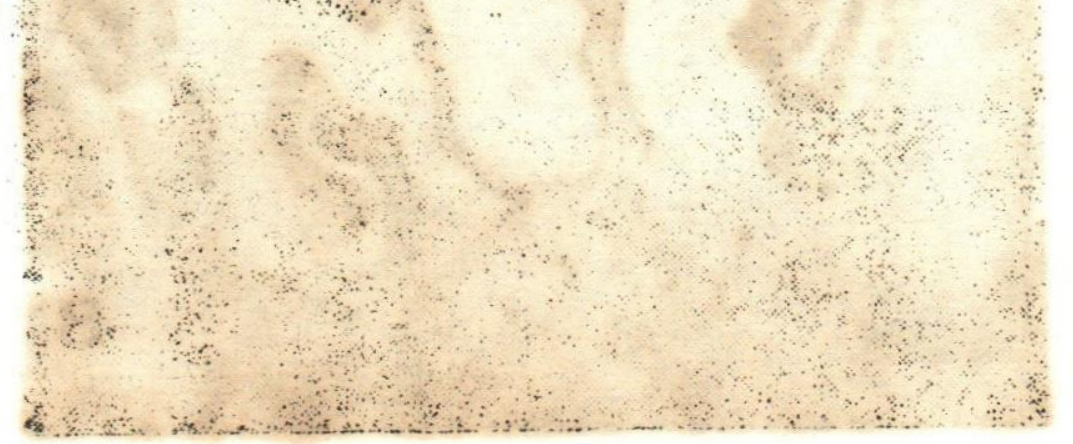



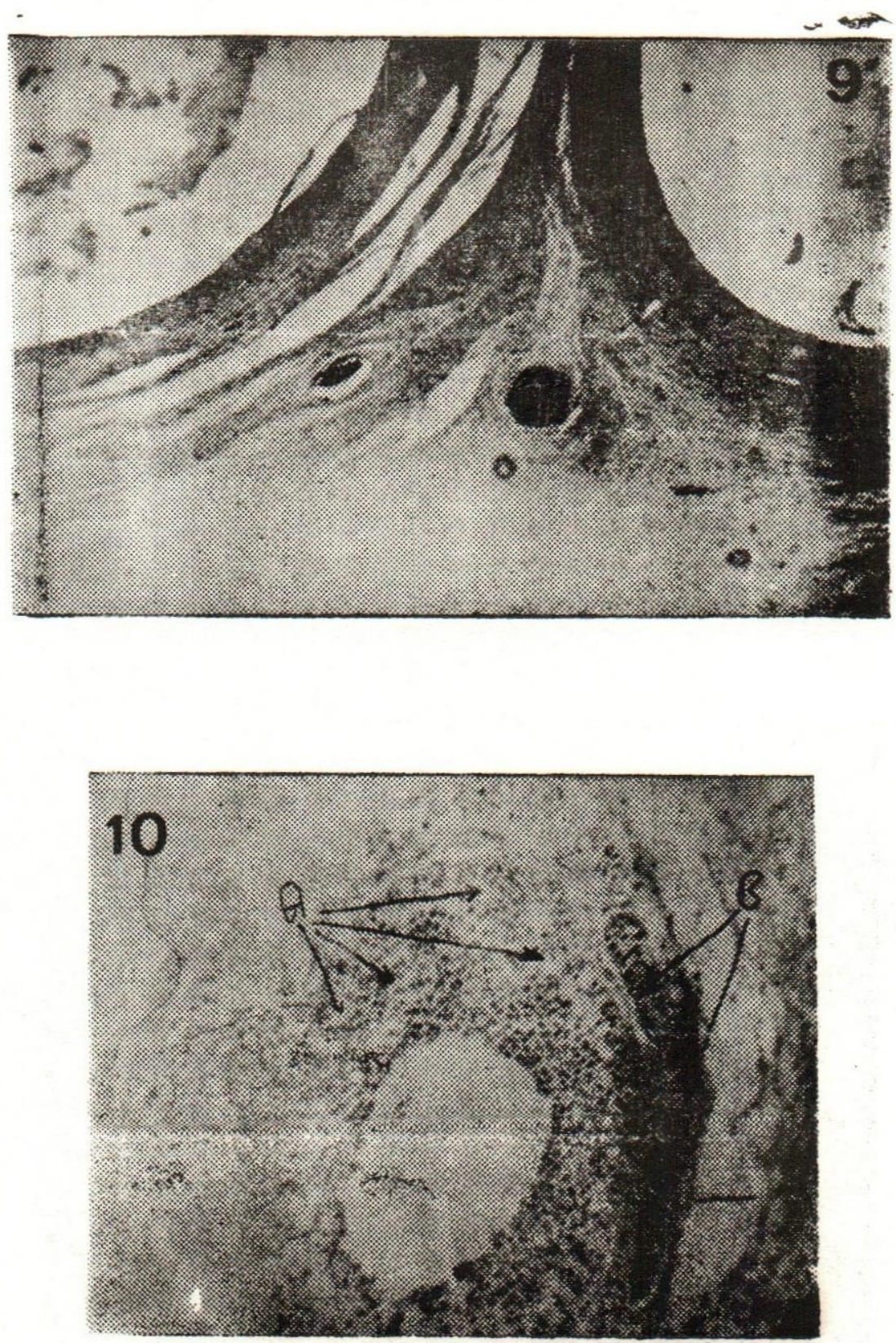

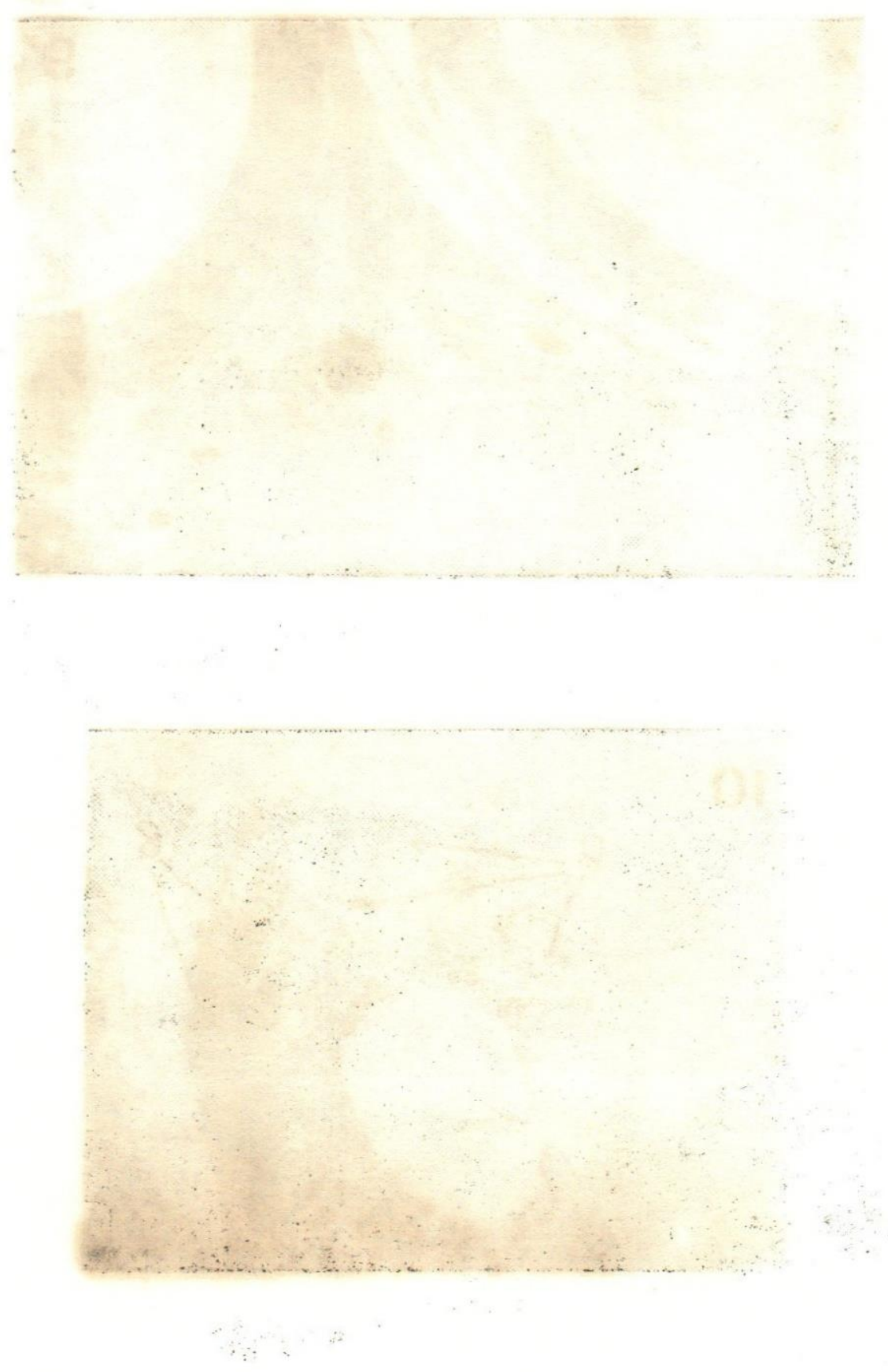

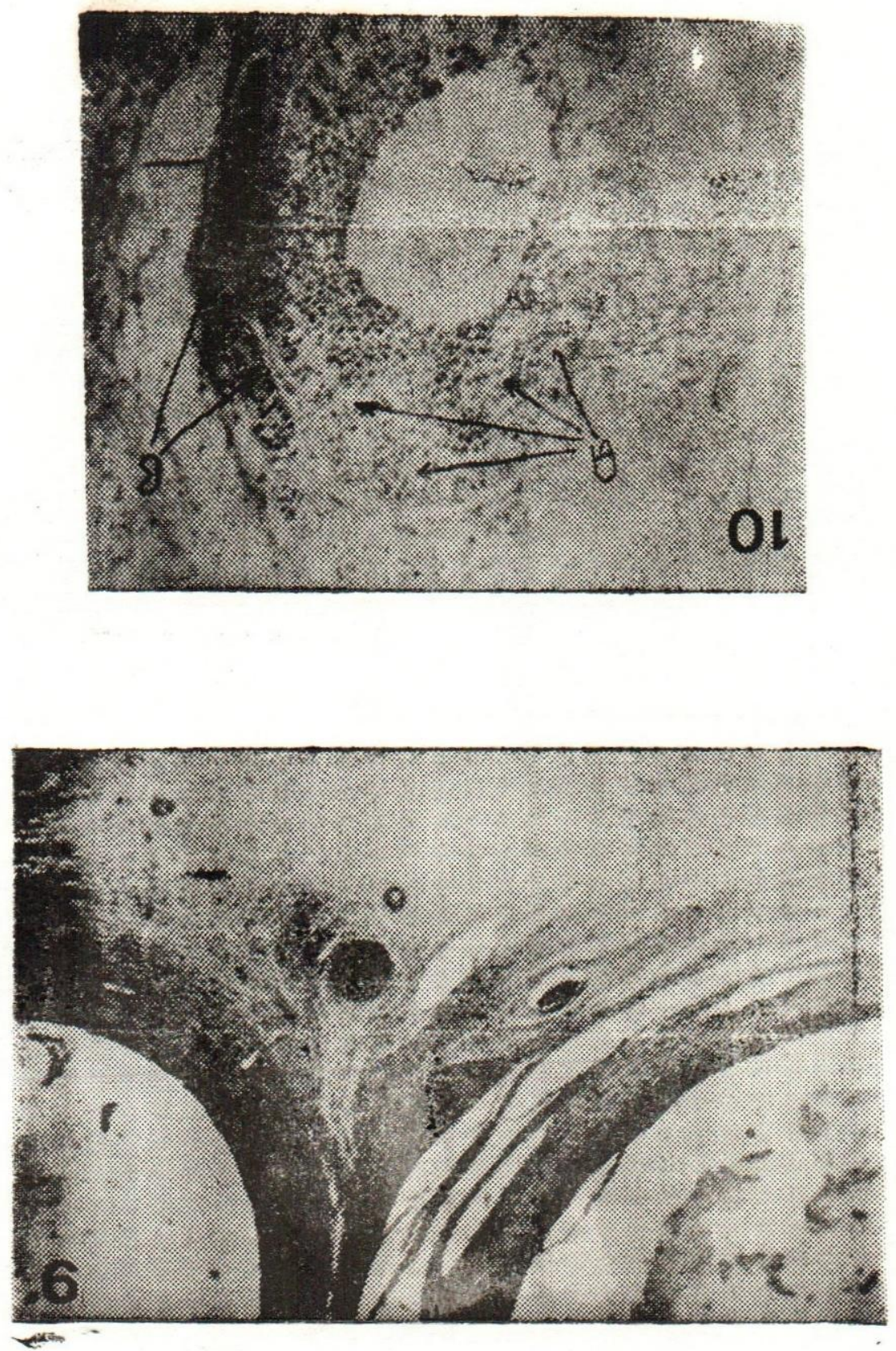


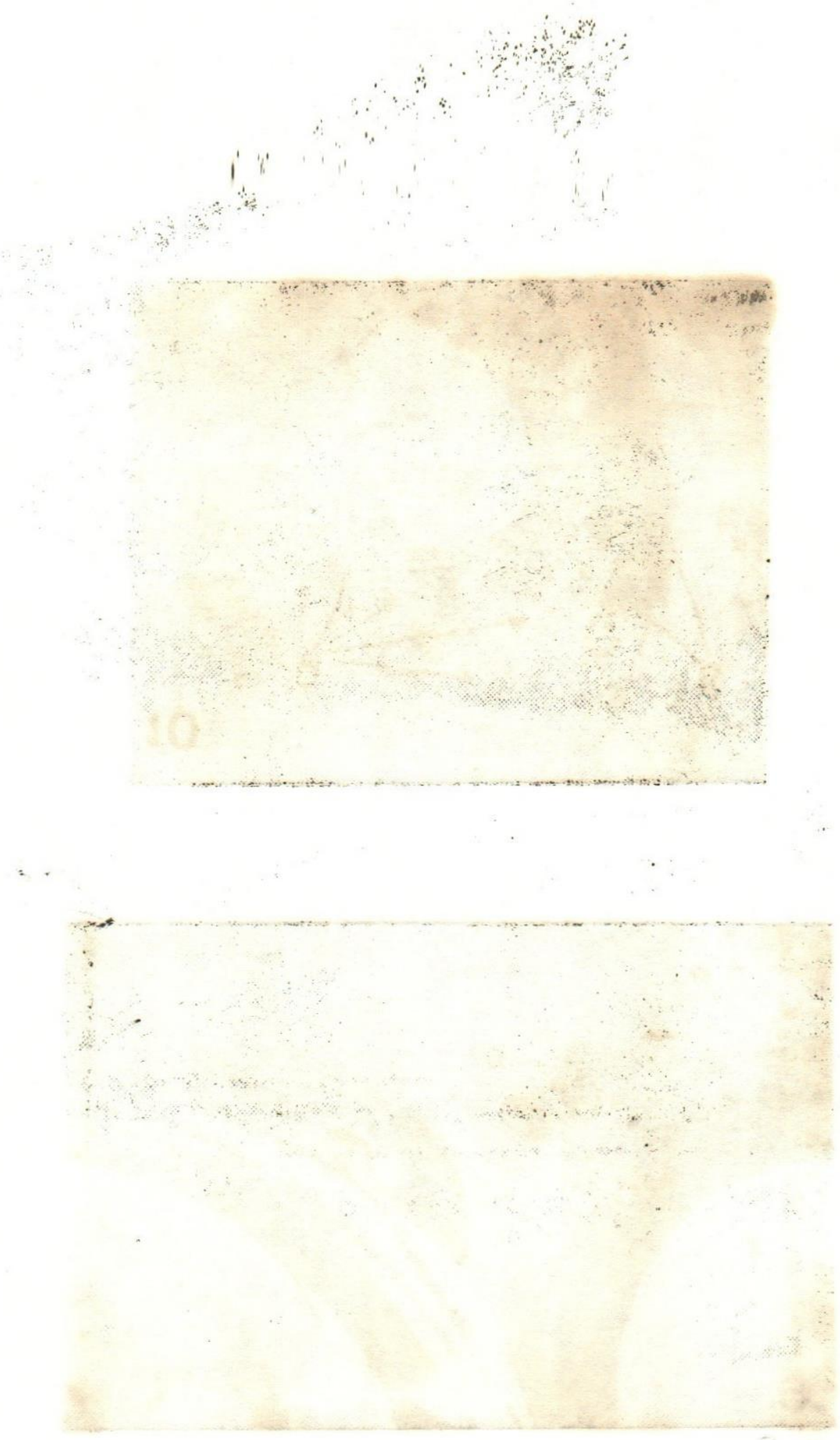

